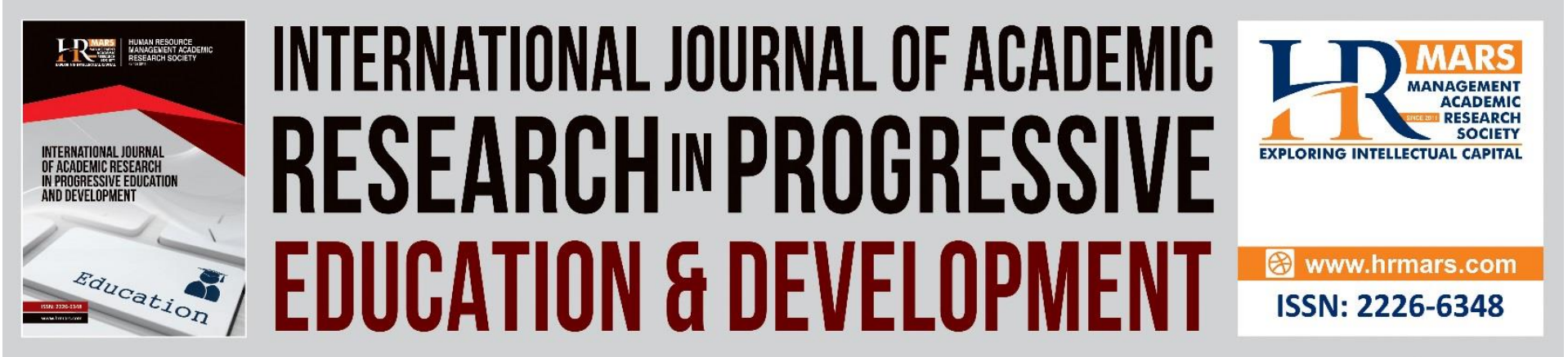

\title{
Ideas for Designing Better Quizzes: A Literature Review and Suggestion
}

Noor Azimah Surip, Zulkifli Mat Som, Muthukumar B. Palanisamy, Mazliza Mohamad

To Link this Article: http://dx.doi.org/10.6007/IJARPED/v10-i3/10423

DOI:10.6007/IJARPED/v10-i3/10423

Received: 08 June 2021, Revised: 12 July 2021, Accepted: 28 July 2021

Published Online: 21 August 2021

In-Text Citation: (Surip et al., 2021)

To Cite this Article: Surip, N. A., Som, Z. M., Palanisamy, M. B., \& Mohamad, M. (2021). Ideas for Designing Better Quizzes: A Literature Review and Suggestion. International Journal of Academic Research in Progressive Education and Development, 10(8), 190-201.

Copyright: (C) 2021 The Author(s)

Published by Human Resource Management Academic Research Society (www.hrmars.com)

This article is published under the Creative Commons Attribution (CC BY 4.0) license. Anyone may reproduce, distribute, translate and create derivative works of this article (for both commercial and non-commercial purposes), subject to full attribution to the original publication and authors. The full terms of this license may be seen

at: http://creativecommons.org/licences/by/4.0/legalcode

Vol. 10(3) 2021, Pg. 190 - 201

Full Terms \& Conditions of access and use can be found at http://hrmars.com/index.php/pages/detail/publication-ethics 


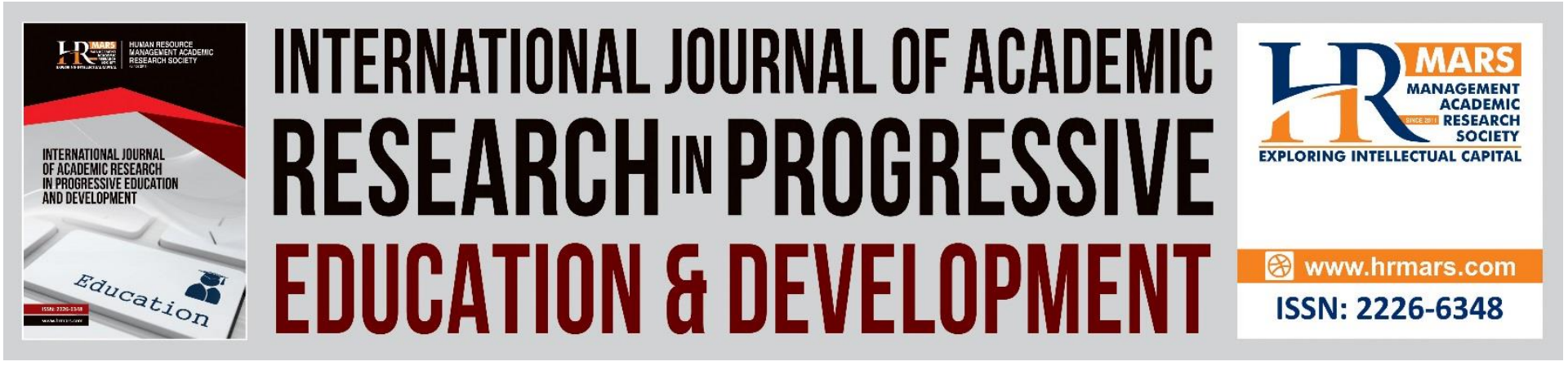

\title{
Ideas for Designing Better Quizzes: A Literature Review and Suggestion
}

\author{
Noor Azimah Surip ${ }^{1}$, Zulkifli Mat Som², Muthukumar B. \\ Palanisamy $^{3}$, Mazliza Mohamad ${ }^{4}$ \\ Institute of Teacher Education, Malaysia \\ Email: noorazimah1979@gmail.com
}

\begin{abstract}
Regarded as a popular type of assessment to test students' knowledge, quiz have a tendency of increasing student's motivation and potential due to its informal, fast and easy to administer nature. It is also deemed as an efficient tool to administer response regarding comprehension of topics taught. This article discusses the practice of quiz as an assessment tool in testing learning outcomes through the results of literature review. Previous studies have shown that quizzes could be conducted to assess learning achievement in the form of score or training practice. The diversity of methods and types of quizzes was put forth to evaluate the learning outcomes of students not only on paper but also online. However, the design of quiz was not explicitly stated as the courses and learning objectives are diversified. Hence, this article has suggested some guidance to teachers in designing a more effective and systematic form of quizzes according to the needs and objectives stipulated.
\end{abstract}

Keywords: Quizzes, Assessment, Teaching and Learning

Introduction

Assessment can be categorized into three main objectives: assessment for learning, assessment as learning and assessment of learning. Assessment for learning happens when an instructor uses students' learning evidence to make judgement on the student's achievement based on certain standards. One type of assessment for learning is quizzes.

Quizzes, generally used as a formative assessment, are regarded as a form of assessment which requires shorter time as it is more simple and less formal. The use of quiz as an assessment is flexible where it can be used in or out of class; in written form, online, as well as through group or individual discussion. According to Roediger et al. (2011), quiz permits students to discover gaps in their knowledge and focus more on difficult or demanding topics. Quizzing also enables better metacognitive monitoring for both students and teachers because it provides feedback as to how well the learning is progressing. Effective learning would occur in educational settings if students used self-testing as a study strategy and were quizzed more frequently in class.

Quizzes can be categorized according to policies and practices that support assessment and evaluation in teaching and learning. Based on the support of evaluation practice, a quiz can be of two types namely graded and non-graded quiz (Chauhan, 2017). 
Graded quiz refers to the assignment of a value for each answer or response given by a student depending on the grading policy used. Quizzes like this are usually implemented in stages and students' marks obtained from the overall results of the quiz will be tabulated at the end of the course as a final grade. Non-graded quiz on the other hand is a question and answer activity or feedback from students, which does constitute any grade. This type of quiz is not taken into account in the final assessment of the course. The non-graded quiz can be done repeatedly without any limit as the marks obtained will not be included for their final assessment.

\section{Quiz in the Form of Formative and Summative}

Formative assessment aims to gather information on students' progress on the learning outcomes of a course delivered while summative assessment is an assessment of students as a whole that will usually be tested at the end of the course. Previous scholars have various views in justifying quiz as an assessment in the form of formative or summative assessment. According to Cohen and Sasson (2016), quizzes are more likely to be formative. This view is in line with several other scholars such as Black and William (1998); Brookhart (2007); Cizek (2007); Harlen (2007) who described quiz as an assessment techniques, as informal tests given to students on an ongoing basis. Furthermore, previous studies have agreed that formative quizzes will improve students' performance on subsequent written summative exams (Zhang et al., 2015)

Quizzes can also be used as complementary formative as well as summative assessment tools (Pedder \& James, 2012; Zuhriyah \& Protolo, 2020). To categorize the quiz as a form of summative assessment, the basis that needs to be considered is that the quiz questions submitted to students must contain the integration of Lower Order Cognitive (LOC) and Higher Order Cognitive (HOC) questions. Quiz items to be tested should reach the level of testing students' abilities in applying, analyzing and critically evaluating the results of the entire learning, and not just the level of knowledge, understanding or memorization. In addition, the level of difficulty for each quiz should be developed based on the topics in the unit to be tested. Quiz questions will start with low -level thinking skills and then develop to higher levels. The emphasis on quizzes involving the HOC level is seen as necessary as one of the alternative approaches that can replace in-class examinations (Tienson-Tseng, 2019). However, there is another challenge to consider is that summative quiz requires a certain amount of time and is risky to give room for plagiarism between students (Aravinthan \& Aravinthan, 2010).

\section{An Overview of Quiz Question Types}

Depending on the course learning outcomes presented, quiz questions should be constructed in alignment with the level of difficulty to be tested on the students. Generally, quizzes are used for two reasons; to assess students' performance, and for training purposes to facilitate students to check their level of understanding of the courses learnt. Quizzes can be divided into two types:

- Performance-based quiz which aims to help instructors evaluate student performance in the form of scores or marks as Outcome Based Education (OBE).

- Practice-based quiz which is used only for training purposes primarily to provide immediate feedback to students for self-assessment, without having to worry about the impact of their scores on the final result. 
DEVELOPMENT

Vol. 10, No. 3, 2021, E-ISSN: 2226-6348 @ 2021 HRMARS

Instructors are given the option to choose one of (or both) the appropriate methods to be implemented in the assessment of students. This consideration is necessary so that the selection of the quiz design is in accordance with best practices in the next teaching in order to improve students' learning so that the learning objectives are achieved as planned. (Enders, Gaschler \& Kubik, 2020: Wallihan et al., 2018; Saidah 2020; Suzana \& Jamil, 2012).

Quizzes can be constructed from a number of questions involving different types of groups such as, Multi Choice Question (MCQ), True / False, descriptive, numerical, based on pictures according to the objectives of student learning outcome. Commonly, the mix of different assessment method is recommended to be used (Chauhan, 2017). The mix of evaluation methods for quizzes such as this is recommended for questions that have formative and summative inclusions consisting of various levels-multiple choice, selecting from a dropdown menu, entering a numerical or short text answer, uploading sketches, dragand-drop labels and reflective and detailed descriptive (essay) type questions. (Gamage, Ayres, Behrend and Smith, 2019).

\section{Problem Statement}

In general, the results of previous studies has agreed in stating that the frequency with which students respond to quiz activities in learning will help them perform better in subsequent tests as well as in final exams (Klinget al., 2005; Anderson et al., 2007, McDaniel, Roediger, et al., 2007; McDaniel et al., 2011; Saidah 2020). A study by Palmel (2015) found that when quizzes were optional, students didn't take advantage of them, while conversely, students who were offered points (even as little as $2 \%$ ), took the quizzes and did statistically better in the exams. The research shows that there was no difference between the frequency of the quizzes, either daily or weekly; and performance. In addition, past studies have shown different opinions regarding performance-based quizzes in the form of scores or mark to final result (Heise et al., 2020; Rusio, 2001; Johnson \& Kiviniemi, 2009; Ross et al., 2018); In addition, the form, type of questions as well as the total number of quiz questions as a testing tool conducted on students also vary.

\section{Proposal and Solution}

Based on the literature review, there are various suggestions made by researchers for the adaptation of quiz implementation methods that can be used in formative and summative assessment as shown in Table 1. 


\begin{tabular}{|c|c|c|c|}
\hline Author/Year & Title & Methodology & Proposed strategy \\
\hline $\begin{array}{l}\text { Tienson- } \\
\text { Tseng, H. L. } \\
\text { (2019) }\end{array}$ & $\begin{array}{l}\text { Best Practices in } \\
\text { Summative } \\
\text { Assessment. In } \\
\text { Biochemistry } \\
\text { Education: From } \\
\text { Theory to Practice }\end{array}$ & Text Study & $\begin{array}{l}\text { - May take the quiz at } \\
\text { different times. } \\
\text { Given the time limitations, it } \\
\text { can be more difficult to test } \\
\text { higher order cognitive skills } \\
\text { on quizzes, } \\
\text { - Online quizzes are } \\
\text { best used as pre-class } \\
\text { assignments }\end{array}$ \\
\hline $\begin{array}{l}\text { Ross, } \\
\text { Chase, A. M., } \\
\text { Robbie, D., } \\
\text { Oates, G., \& } \\
\begin{array}{l}\text { Absalom, } \\
(2018)\end{array}\end{array}$ & $\begin{array}{l}\text { Adaptive quizzes to } \\
\text { increase motivation, } \\
\text { engagement and } \\
\text { learning outcomes in a } \\
\text { first year accounting } \\
\text { unit }\end{array}$ & $\begin{array}{l}\text { Data } \\
\text { collection } \\
\text { included both } \\
\text { qualitative } \\
\text { and } \\
\text { quantitative } \\
\text { data. }\end{array}$ & $\begin{array}{l}\text { - Adaptive on line quizzes } \\
\text { were introduced ( } 25 \%) \\
\text { - } 3 \text { levels of difficulty for each } \\
\text { quiz were developed for } \\
\text { each of the different topic } \\
\text { areas covered in the unit. }\end{array}$ \\
\hline $\begin{array}{l}\text { Siti Zuhriyah, } \\
\text { Bambang } \\
\text { Widi Pratolo } \\
\text { (2020) }\end{array}$ & $\begin{array}{l}\text { Exploring Students' } \\
\text { Views in the Use of } \\
\text { Quizzes as an } \\
\text { Assessment Tool in } \\
\text { English as a Foreign } \\
\text { Language (EFL) Class. }\end{array}$ & $\begin{array}{l}\text { A case study } \\
\text { as a method. } \\
\text { A semi- } \\
\text { structured } \\
\text { interview was } \\
\text { utilized to } \\
\text { gather the } \\
\text { data. }\end{array}$ & $\begin{array}{l}\text { - On line quiz } \\
\text { - Live quiz or homework quiz } \\
\text { - Use the skimming strategy to } \\
\text { identify the point of each } \\
\text { question. }\end{array}$ \\
\hline $\begin{array}{l}\text { Sanchez, D. } \\
\text { R., Langer, } \\
\text { M., \& Kaur, R. } \\
\text { (2020) }\end{array}$ & $\begin{array}{l}\text { Gamification in the } \\
\text { classroom: Examining } \\
\text { the impact of gamified } \\
\text { quizzes on student } \\
\text { learning. }\end{array}$ & $\begin{array}{l}\text { Quasi- } \\
\text { experimental } \\
\text { design, }\end{array}$ & $\begin{array}{l}\text { Traditional quiz/ On line quiz } \\
\text { to complete a series across } \\
\text { all the topics during } \\
\text { semester. } \\
\text { - Course credit was awarded } \\
\text { to students for completing } \\
\text { the quizzes (5 points) }\end{array}$ \\
\hline $\begin{array}{l}\text { John Ruscio } \\
\text { (2001) }\end{array}$ & $\begin{array}{l}\text { Administering Quizzes } \\
\text { at Random to Increase } \\
\text { Students' Reading }\end{array}$ & Quantitative & $\begin{array}{l}\text { - } \quad \text { Administer quizzes regularly } \\
\text { - } \quad \text { scheduled quizzes } \\
\text { of the course grade }\end{array}$ \\
\hline
\end{tabular}




\begin{tabular}{|c|c|c|c|}
\hline $\begin{array}{l}\text { Salas- } \\
\text { Morera, L., } \\
\text { Arauzo- } \\
\text { Azofra, A., \& } \\
\text { García- } \\
\text { Hernández, L. } \\
\text { (2012) }\end{array}$ & $\begin{array}{l}\text { Analysis of online } \\
\text { quizzes as a teaching } \\
\text { and assessment tool. }\end{array}$ & Experiment & $\begin{array}{l}\text { - } 6 \text { on line quizzes, evenly } \\
\text { spread out during the } \\
\text { semester. } \\
\text { - } 25 \% \text { for final grade }\end{array}$ \\
\hline $\begin{array}{l}\text { Markié, M. } \\
\text { (2017) }\end{array}$ & $\begin{array}{l}\text { September). } \\
\text { Evaluation of quiz } \\
\text { using a statistical } \\
\text { calculation in Learning } \\
\text { Management System. }\end{array}$ & Experiment & - 5 quizzes during semester \\
\hline $\begin{array}{l}\text { Brian Robert } \\
\text { Cook and } \\
\text { Andrea } \\
\text { Babon (2016) }\end{array}$ & $\begin{array}{lr}\text { Active } & \text { learning } \\
\text { through } & \text { online } \\
\text { quizzes: } & \text { better } \\
\text { learning and } & \text { less } \\
\text { (busy) work } & \end{array}$ & Mix-method & $\begin{array}{l}\text { - } \text { Regular, weekly online } \\
\text { quizzes } \\
\text { Quizzes worth } 20 \% \text { of total } \\
\text { student marks } \\
\text { - Quiz questions should be } \\
\text { designed to be of moderate } \\
\text { difficulty and should be } \\
\text { easily answered by student }\end{array}$ \\
\hline $\begin{array}{l}\text { Braun, K. W., } \\
\text { \& Sellers, R. } \\
\text { D. (2012) }\end{array}$ & $\begin{array}{l}\text { Using a "Daily } \\
\text { Motivational Quiz" to } \\
\text { Increase Student } \\
\text { Preparation, } \\
\text { Attendance, and } \\
\text { Participation }\end{array}$ & Quantitative & $\begin{array}{l}\text { - Daily Quizzes ( } 5 \text { minutes) } \\
\text { - } 25 \% \text { of the final course grade } \\
\text { - Students pick up the daily } \\
\text { quiz as they arrive in class. }\end{array}$ \\
\hline $\begin{array}{l}\text { Johnson, B. } \\
\text { C., and } \\
\text { Kiviniemi, M. } \\
\text { T. (2009) }\end{array}$ & $\begin{array}{l}\text { The Effect of Online } \\
\text { Chapter Quizzes on } \\
\text { Exam Performance in } \\
\text { an Undergraduate } \\
\text { Social Psychology } \\
\text { Course }\end{array}$ & Quantitative & $\begin{array}{l}\text { - Quizzes contributed } 6 \% \text { to } \\
\text { final course grade } \\
\text { - } \quad \text { Regularly scheduled quizzes } \\
\text { - } 8 \text { quizzes during the } \\
\text { semester } \\
\text { - Complete the quizzes before } \\
\text { class session in which related } \\
\text { topics were covered }\end{array}$ \\
\hline $\begin{array}{l}\text { Gamage, S. } \\
\text { H., Ayres, J. } \\
\text { R., Behrend, } \\
\text { M. B., Smith, } \\
\text { E. J. (2019) }\end{array}$ & $\begin{array}{l}\text { Optimising Moodle } \\
\text { quizzes for online } \\
\text { assessments }\end{array}$ & Quantitative & $\begin{array}{l}\text { - } \text { Online Quizzes } \\
\text { - } \quad \text { Automated marking } \\
\text { - } \text { Randomising and shuffling } \\
\text { quiz questions. } \\
\text { - } \text { Formative \& summative } \\
\text { Moodle quizzes were } \\
\text { developed }\end{array}$ \\
\hline
\end{tabular}




\begin{tabular}{|c|c|c|c|}
\hline $\begin{array}{lll}\text { Latif, } & \text { E., } & \& \\
\text { Miles, } & \text { S. } \\
(2020) & \end{array}$ & $\begin{array}{l}\text { The Impact of } \\
\text { Assignments and } \\
\text { Quizzes on Exam } \\
\text { Grades. A Difference- } \\
\text { in-Difference } \\
\text { Approach. }\end{array}$ & $\begin{array}{c}\text { Quasi- } \\
\text { Experimental }\end{array}$ & $\begin{array}{l}\text { - A total of } 8 \text { quizzes, each } \\
\text { consisting of multiple-choice } \\
\text { questions. } \\
\text { Using the question } \\
\text { bank's difficulty rating to } \\
\text { ensure that the level of } \\
\text { difficulty }\end{array}$ \\
\hline $\begin{array}{l}\text { Heise, N., } \\
\text { Meyer, C. A., } \\
\text { Garbe, B. A., } \\
\text { Hall, H. A., \& } \\
\text { Clapp, T. R. } \\
(2020)\end{array}$ & $\begin{array}{l}\text { Table quizzes as an } \\
\text { assessment tool in the } \\
\text { gross anatomy } \\
\text { laboratory. }\end{array}$ & Quantitative & $\begin{array}{l}\text { - Weekly quizzes comprised } \\
\text { the } 20 \% \text {. } \\
\text { - Around } 10 \text { minutes } \\
\text { - At the end of the semester, } \\
\text { students were allowed to } \\
\text { drop } 1 \text { (lowest) weekly table } \\
\text { quiz grade }\end{array}$ \\
\hline $\begin{array}{l}\text { Hennig, S., } \\
\text { Staatz, C. E., } \\
\text { Bond, J. A., } \\
\text { Leung, D., \& } \\
\text { Singleton, J. } \\
(2019)\end{array}$ & $\begin{array}{l}\text { Quizzing for success: } \\
\text { Evaluation of the } \\
\text { impact of feedback } \\
\text { quizzes on the } \\
\text { experiences and } \\
\text { academic } \\
\text { performance of } \\
\text { undergraduate } \\
\text { students in two } \\
\text { clinical } \\
\text { pharmacokinetics } \\
\text { courses }\end{array}$ & Quantitative & $\begin{array}{l}\text { - } 7 \text { times weekly summative, } \\
\text { online quizzes, outside } \\
\text { allocated class time } \\
20 \% \text { of the total grade for } \\
\text { the course. } \\
\text { The question types included } \\
\text { multiple choice, case } \\
\text { scenarios, true/false, and fill } \\
\text { in the blank. }\end{array}$ \\
\hline $\begin{array}{l}\text { Angus, S. D., } \\
\& \text { Watson, J. } \\
(2009)\end{array}$ & $\begin{array}{l}\text { Does regular online } \\
\text { testing enhance } \\
\text { student learning in } \\
\text { the numerical } \\
\text { sciences? Robust } \\
\text { evidence from a large } \\
\text { data set. }\end{array}$ & Quantitative & $\begin{array}{l}\text { - } 4 \text { quizzes ( } 2 \text { marks each quiz) } \\
\text { - } \quad \text { Comprised } 8 \% \text { of final grade } \\
\text { - } \quad \text { Formative quizzes. }\end{array}$ \\
\hline
\end{tabular}

Based on the above literature review related to the implementation of quizzes as an assessment tool, this article has suggested some ideas for designing better quizzes. It can be seen as an effective and efficient method in measuring students' performance and achievement.

\section{Adaptive Quizzes}

Adaptive quizzes are implemented for students to make appropriate preparations in preparing for the summative assessment. This type of quiz is also a mechanism to increase students' self -motivation to continue to progress throughout the teaching and learning period. Student learning outcomes will be compared based on quiz assessments. Adaptive 
testing is a system of testing that changes to meet a student's current level of mastery on an ongoing basis. The level of quiz assignments is given based on the level at the initial stage. The difficulty level will be increased if the quiz task is successfully completed. The difficulty level will be lowered otherwise. This type of quiz model aims to measure students' current level of achievement more accurately. Adaptive quiz questions presented to students are periodic and given randomly according to the topics covered in the course throughout the semester. Quizzes are designed and arranged to support the development of concepts and understanding in preparing for assessment by asking appropriate questions and spacing the quiz time throughout the teaching period as well as being able to provide immediate feedback. Students will answer a quiz of multiple choice answers taken from a group of questions from a number of specific topics that have not been or have been taught. The number of quizzes varies by semester. The result of the study shows that the implementation of adaptive quizzes can indeed contribute to student motivation and engagement. The students themselves felt that the adaptive quizzes greatly supported their learning (Barla et al. 2010; Ross et al., 2018).

\section{Weekly/ Regular Quiz}

Regular, weekly quizzes are preferable to assess student learning outcomes. According to Ross et al. (2018), students felt that the weekly quizzes provided a means of continually testing whether their knowledge was up to the level it needed to be and identifying which areas they needed to work more on. Weekly quizzes are great for keeping on top of the readings, and giving an indication of progress. It can also promote deeper engagement with the content, further the development of important learning skills, and provide teachers and students with feedback that promotes learning. Thus, students will not be too overwhelmed by the concepts given in lectures. Students' feedback obtained through this strategy can help improve students' knowledge and skills, and further reduce comparisons and achievement gaps between them.

\section{Online Quizzes}

Depending on the structure and objectives of the questions, online quizzes with a variety of state-of-the-art applications are more efficient, effective and easier for students to answer than quizzes on paper and pencil (Marriott \& Lau, 2008; Segall, Doolen, \& Porter, 2005). In line with the advancement of the current multimedia and communication technology, this virtual method provides space and opportunity for students to answer questions repeatedly. Among other advantages is that online quizzes can be used to save class time and for automated grading (Teonson-Tseng 2019). However, these online quizzes is costly as students need to have their own devices such as computers, tablets, mobile phones and even a stable internet line. Most institutes of higher learning and colleges have created their own Learning Management System (LMS) in managing online learning in their institutions systematically (Houlden \& Veletsianos, 2020), either through Moodle or other LMS applications such as Edmodo, Google Classroom, and ClassDojo.

\section{Collaborative Quizzes}

Not only limited to being implemented individually, quizzes can also be set to be completed in small groups. In groups, students will work together to brainstorm and help each other to achieve learning objectives. The advantage of such a method is that it can encourage students 
to better understand and reinforce a topic related to the course studied (Petrunich et al (2019). The competition that exists between other quiz groups will create a more exciting and fun educational environment. This statement is in line with the previous studies in relation to students' positive perception of collaborative quizzes (Cotright, 2003; Haberyan, 2010; Woody, 2008). Likewise, a study on the students' perception for a portion of the semester or the entire semester were equally positive (Enz et al., 2015). However, the questions and discussion submitted through group quizzes should not be retested on individual tests.

\section{Quiz Marks As Students' Final Grading}

Quizzes are among the main options that are widely applied by universities and colleges as one of the methods of giving grades to students. However, the selection of a standard quiz in terms of the criteria and the amount of grading is usually determined by a team of professional instructors at a school itself. The analysis of this study shows that a total of 5 to 10 percent is sufficient to be taken to the final grading of the course for low level quiz questions. However a weightage of 15 to 25 percent should be considered for quiz questions involving high level questions. However, the number of quizzes conducted should be considered as appropriate whether to be implemented weekly or periodically. Quiz credits will then be taken and accumulated with other test scores for the purpose of final grading of the course at the end of the semester.

\section{Things to Consider}

Identifying suitable Course Learning Outcomes (CLO) for testing through quizzes. Instructors need to identify specific topics with the appropriateness of questions according to the taxonomy level as representing the domains of knowledge and skills taught. Accordingly, the Test Specification Table (TST) is highly recommended as one of the best practice methods in education. Also known as the "test blueprint", TST is a table or matrix that guides and assists the instructor for the purpose of coordinating instructions, and the objective level of the questions to be tested in the assessment (Notar et al., 2004; Zimmaro 2004). In line with this purpose, TST in assessment should be considered to ensure that question items submitted through quizzes can be formulated fairly according to topics, cognitive needs and number of student learning hours that have been aligned based on course learner outcomes (CLO) to be assessed.

The appropriateness of its implementation should be in line with the suggestions or ideas as submitted by previous researchers. The medium for quiz is more suitable to be implemented periodically whether scheduled or otherwise. With a variety of questioning methods either orally or in writing, online or traditionally and individually or in groups, repeated quiz implementation can influence students to have high reading readiness, increase motivation and performance, thereby helping to achieve different cognitive skills.

\section{Conclusion}

Quizzes can undoubtedly be used as a tool to test the level of student achievement in certain aspects to guide them to be more focused and motivated towards organizing self-learning that can ultimately improve their performance (Karpicke \& Roediger, 2007; McDaniel et al., 2011; Roediger \& Karpicke, 2006b; Roediger, McDermott, \& McDaniel, 2011; Roediger, Putnam, \& Smith, 2011). Although quizzes are more likely seen as formative assessment, the scores obtained from quiz assessment can be used as an incentive to be taken to the final 
grade and accumulated with other assignments such as coursework and final exams. Thus, to ensure that the quiz becomes part of a more meaningful assessment method, the implementation method and quiz question items must be based on ideas and have a high quality design and validity.

Each lecturer has a specific strategy for assessing the achievement of his or her students (Airasian, 1994; Linn \& Gronlund, 1995; Pelleringo, Chudowsky \& Glaser, 2001). The findings of this study clearly show that quizzes are among the significant methods in determining the purpose of assessment to identify weaknesses and strengths of students, to improve teaching and assess student progress in turn provide results on student achievement. All these inputs are necessary to help instructors achieve the goals and objectives of the study program. (Stufflebeam, 2003)

In accordance to the findings of this study, it was also suggested that some realistic and ideal quiz strategies be implemented by lecturers for assessment purposes due to its flexibility, which can cover each course and program at all levels of study including colleges or institutes of higher learning. Future studies are recommended to further explore the ability of instructors in formulating quiz question with high validity and reliability in influencing students' performance.

\section{References}

Airasian, P. W. (1994). Classroom assessment. New York: McGraw-Hill.

Alzughaibi, M., Alotaibi, M., Ahmed, F., Alqahtani, B., \& Bargo, M. (2016). PBL quizzes and their effects on student performance. Journal of US-China Medical Science, 13, 108112.

Aravinthan, V., \& Aravinthan, T. (2010, July). Effectiveness of self-assessment quizzes as a learning tool. In Proceedings of Engineering Education Conference (EE 2010). Higher Education Academy Subject Centres for Materials and Engineering.

Bennett, R. E. (2011). Formative assessment: A critical review. Assessment in education: principles, policy \& practice, 18(1), 5-25. https://doi.org/10.1080/0969594X.2010.513678

Brookhart, S. M. (2011). Teacher feedback in formative classroom assessment. In Leading student assessment (pp. 225-239). Springer, Dordrecht.

Chappuis, J. (2009). Seven strategies for assessment of learning. Boston: Pearson.

Chauhan, J., \& Goel, A. (2017). Quiz in MOOC: An overview. International Research Journal of Engineering and Technology, 4, 303-307.

Clump, M. A., Bauer, H., \& Whiteleather, A. (2003). To attend or not to attend: Is that a good question? Journal of Instructional Psychology, 30(3).

Cortright, R. N., Collins, H. L., Rodenbaugh, D. W., \& DiCarlo, S. E. (2003). Student retention of course content is improved by collaborative-group testing. Advances in Physiology Education, 27(3), 102-108.

Djamàa, S. (2020). Lecture in the Living Room, Homework in the Classroom: The Effects of Flipped Instruction on Graduate EFL Students' Exam Performance. Computers in the Schools, 37(3), 141-167.

Enz, S., \& Frosch, D. R. (2015). Effect of collaborative vs noncollaborative quizzes on examination scores in a pharmaceutical calculations course. American journal of pharmaceutical education, 79(5).

Faiza, M. A. R., Bashir, M. U., Naeem, S., \& Arshad, S. (2019). Using online practice quizzes 
Figueroa-Cañas, J., \& Sancho-Vinuesa, T. (2019). Predicting early dropout student is a matter of checking completed quizzes: the case of an online statistics module. In LASISPAIN (pp. 100-111).

Gamage, S. H., Ayres, J. R., Behrend, M. B., \& Smith, E. J. (2019). Optimising Moodle quizzes for online assessments. International Journal of STEM Education, 6(1), 1-14.

Haberyan, A., \& Barnett, J. (2010). Collaborative testing and achievement: are two heads really better than one?. Journal of Instructional Psychology, 37(1).

Heise, N., Meyer, C. A., Garbe, B. A., Hall, H. A., \& Clapp, T. R. (2020). Table quizzes as an assessment tool in the gross anatomy laboratory. Journal of Medical Education and Curricular Development, 7, 2382120520941822.

Hennig, S., Staatz, C. E., Bond, J. A., Leung, D., \& Singleton, J. (2019). Quizzing for success: Evaluation of the impact of feedback quizzes on the experiences and academic performance of undergraduate students in two clinical pharmacokinetics courses.Currents in Pharmacy Teaching and Learning,11(7), 742-749. https://doi:10.1016/j.cptl.2019.03.014

Johnson, B. C., \& Kiviniemi, M. T. (2009). The effect of online chapter quizzes on exam performance in an undergraduate social psychology course. Teaching of Psychology, 36(1), 33-37.

Linn, R. L., \& Gronlund, N. E. (1995). Measurement and assessment in teaching, Seventh edition. New York: Macmillan.

Loyd, G. E., \& Koenig, H. M. (2008). Assessment for learning: formative evaluations. International Anesthesiology Clinics, 46(4), 85-96. https://doi.org/10.1097/ALA.0b013e31818623df

Markié, M. (2017, September). Evaluation of quiz using a statistical calculation in Learning Management System. In 2017 25th International Conference on Software, Telecommunications and Computer Networks (SoftCOM) (pp. 1-5). IEEE.

Notar, C. E., Zuelke, D. C., Wilson, J. D., \& Yunker, B. D. (2004). Table of Specifications: Insuring Accountability in Teacher-Made Tests. Journal of Psychology, 31(2)

Pandey, C., \& Kapitanoff, S. (2011). The influence of anxiety and quality of interaction on collaborative test performance. Active Learning in Higher Education, 12(3), 163-174. https://doi:10.1177/1469787411415077

Pedder, D., \& James, M. (2012). Professional learning as a condition for assessment for learning. Assessment and learning, 3(2), 33-48.

Pelligrino, J. W., Chudowsky, N., \& Glaser, R. (Eds.). (2001). Knowing what students know: the science and design of EA. Washington, D.C.: National Academy Press

Petrunich-Rutherford, M. L., \& Daniel, F. (2019). Collaborative quizzes: Impact on student performance and attendance. Teaching of Psychology, 46(2), 115-120.

Qu, W., \& Zhang, C. (2013). The analysis of summative assessment and formative assessment and their roles in college English assessment system. Journal of Language Teaching and Research, 4(2), 335.-339. https://doi.org/10.4304/jltr.4.2.335-339

Roediger III, H. L., Putnam, A. L., \& Smith, M. A. (2011). Ten benefits of testing and their applications to educational practice. Psychology of learning and motivation, 55, 1-36.

Ruscio, J. (2001). Administering quizzes at random to increase students' reading. Teaching of Psychology, 28(3), 204-205.

Saidah, U. H. (2020). Formative Quizzes to Improve Instruction, Student's Participation and Understanding in Academic Writing. Jo-ELT (Journal of English Language Teaching) 
Fakultas Pendidikan Bahasa \& Seni Prodi Pendidikan Bahasa Inggeris IKIP, 3(2), 117126.

Salas-Morera, L., Arauzo-Azofra, A., \& García-Hernández, L. (2012). Analysis of online quizzes as a teaching and assessment tool.JOTSE: Journal of technology and science education, 2(1), 39-45.

Straub, J., Marsh, R., \& Whalen, D. (2017). Small spacecraft development project-based learning. New York, NY: Springer.

Stufflebeam, D. L. (2003). The CIPP Model for program evaluation. Boston: Kluwer: Nijhoff Publishing

Vagholkar, K. (2019). OSCE as a Summative Assessment Tool for Undergraduate Students of Surgery-Our Experience. Indian Journal of Surgery, 81(4), 412-412. https://doi.org/10.1007/s12262-018-1827-z

Woody, W. D., Woody, L. K., \& Bromley, S. (2008). Anticipated group versus individual examinations: A classroom comparison. Teaching of Psychology, 35(1), 13-17.

Zhang, N., \& Henderson, C. N. (2015). Can formative quizzes predict or improve summative exam performance?. Journal of Chiropractic Education, 29(1), 16-21.

Zhao, F. (2019). Using Quizizz to Integrate Fun Multiplayer Activity in the Accounting Classroom. International Journal of Higher Education, 8(1), 37-43. https://doi.org/10.5430/ijhe.v8n1p37

Zimmaro, D. M. (2004). Writing good multiple-choice exams. Measurement and Evaluation Center. University of Texas. Retrieved August 16, 2009, from http://www.utexas.edu/academic/mec/research/pdf/writingmcexamshandout.pdf

Zuhriyah, S., \& Pratolo, B. W. (2020). Exploring Students' Views in the Use of Quizizz as an Assessment Tool in English as a Foreign Language (EFL) Class. Universal Journal of Educational Research, 8(11), 5312-5317. 